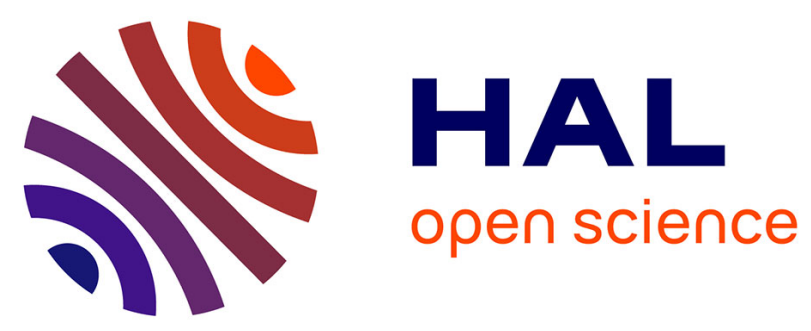

\title{
Cell-bound exopolysaccharides from an axenic culture of the intertidal mudflat Navicula phyllepta diatom affect biofilm formation by benthic bacteria
}

\author{
Ibtissem Doghri, Johann Lavaud, Alain Dufour, Alexis Bazire, Isabelle \\ Lanneluc, Sophie Sablé
}

\section{To cite this version:}

Ibtissem Doghri, Johann Lavaud, Alain Dufour, Alexis Bazire, Isabelle Lanneluc, et al.. Cell-bound exopolysaccharides from an axenic culture of the intertidal mudflat Navicula phyllepta diatom affect biofilm formation by benthic bacteria. Journal of Applied Phycology, 2017, 29 (1), pp.165-177. 10.1007/s10811-016-0943-z . hal-02329553

\section{HAL Id: hal-02329553 https://hal.science/hal-02329553}

Submitted on 13 Nov 2019

HAL is a multi-disciplinary open access archive for the deposit and dissemination of scientific research documents, whether they are published or not. The documents may come from teaching and research institutions in France or abroad, or from public or private research centers.
L'archive ouverte pluridisciplinaire HAL, est destinée au dépôt et à la diffusion de documents scientifiques de niveau recherche, publiés ou non, émanant des établissements d'enseignement et de recherche français ou étrangers, des laboratoires publics ou privés. 


\section{Cell-bound exopolysaccharides from an axenic culture of the intertidal mudflat Navicula phyllepta diatom affect biofilm formation by benthic bacteria}

Ibtissem Doghri, 1

Email ibtissem.doghri@univ-lr.fr

Johann Lavaud, 1,2

Email johann.lavaud@takuvik.ulaval.ca

Alain Dufour, ${ }^{3}$

Email alain.dufour@univ-ubs.fr

Alexis Bazire, ${ }^{3}$

Email alexis.bazire@univ-ubs.fr

Isabelle Lanneluc, 1 ,

Email isabelle.lanneluc@univ-lr.fr

Sophie Sablé, 1

Emailsophie.sable@univ-lr.fr

1 LIENSs, UMR 7266 Université de La Rochelle-CNRS, Univ. La Rochelle, F-17042 La Rochelle Cedex 01, France AQ1

2 Present Address: UMI 3376 TAKUVIK, Département de Biologie, CNRS-Université Laval, Pavillon Alexandre-Vachon, 1045 avenue de la Médecine, Québec, G1V 0A6 Canada

3 EA 3884, LBCM, IUEM, Univ. Bretagne-Sud, F-56100 Lorient, France

\section{Abstract}


At low tide, intertidal mudflat biofilms cover large surfaces and are mainly responsible for the high productivity of these marine areas. In the European Atlantic coast, such biofilms are mainly composed of diatoms, especially Navicula phyllepta, bacteria, and microbial extracellular polymeric substances (EPS). To better understand interactions occurring between microorganisms, we first axenized a $N$. phyllepta culture with a new and simple protocol. Colloidal and bound EPS secreted by diatom cells during the exponential growth and the stationary phase were then harvested, and we tested their effects on the in vitro formation of biofilms by three marine bacteria. The latter had been isolated from a French Atlantic intertidal mudflat and were previously selected for their strong in vitro biofilmforming ability. They belong to the Flavobacterium, Roseobacter, and Shewanella genera. Navicula phyllepta-bound EPS synthesized during the stationary phase specifically inhibited the biofilm formation by the Flavobacterium sp. strain, whereas they stimulated biofilm development by the two other strains. The EPS acted in all cases during the first stages of the biofilm establishment. Saccharidic molecules were found to be responsible for these activities. This is the first report on marine bacterial antibiofilm saccharides of microalgal origin. This work points out the complexity of the benthic natural biofilms with specific microalgae/bacteria interactions and underlines the possibility to use axenic diatoms as a source of bioactive compounds.

\section{Keywords}

Diatoms

Bacteria

Marine biofilms

Exopolysaccharides

Algae-bacteria interactions

Isabelle Lanneluc and Sophie Sablé contributed equally to this work.

\section{Introduction} AQ2

Intertidal mudflats are among the most productive marine areas (Admiraal et al. 1984), and they may provide up to $50 \%$ of the primary production of estuaries, in particular due to the formation of photosynthetic biofilms at their 
surface (Underwood and Kronkamp 1999). By providing shelter and food, mudflats especially serve as pantry and nursery for many animal species of commercial interest, including fishes (Beck et al. 2001).

One of the peculiarities of intertidal mudflat biofilms lies in their transient character. During daily tidal emersion periods, autotrophic motile microalgae (microphytobenthos) move upward through the sediment to the surface to access the light they need for photosynthesis (Consalvey et al. 2004). When microalgae and heterotrophic prokaryotes associate at the surface, they secrete a matrix of mucilaginous extracellular polymeric substances (EPS) and form a biofilm surrounding the sediment particles (Decho 2000; Consalvey et al. 2004 ). During immersion and night, microalgae migrate downward into deeper sediment layers (Consalvey et al. 2004), part of the biofilm biomass is resuspended into the water column, and the temporary biofilm disappears (Colijn 1982; Serôdio et al. 1997).

This transient biofilm is thus mainly composed of microalgae (Admiraal et al. 1984 ; Underwood and Kronkamp 1999), prokaryotes (mainly bacteria) (van Duyl et al. 2000), and a variety of EPS (Underwood and Paterson 2003) constituting complex assemblages of polysaccharides, proteins, glycoproteins, uronic acids, lipids, and many other compounds (Underwood et al. 2004; Pierre et al. 2012). The EPS matrix is believed to limit sediment desiccation by maintaining high pore water content, to stabilize sediment layers, and to protect microorganisms against exogenous stresses (Flemming and Wingender 2010; Orvain et al. 2014). Motile epipelic diatoms secrete into the surrounding sediment 30 to $60 \%$ of photoassimilated carbon as EPS (Underwood et al. 1995; Middelburg et al. 2000; Smith and Underwood 2000 ). In European intertidal mudflats, epipelic diatoms dominate the microphytobenthic community, representing up to $97 \%$ of the biomass (de Jonge and Colijn 1994; Méléder et al. 2005 ). In the French Atlantic coast, the dominant species is Navicula phyllepta (Haubois et al. 2005). Whereas bacteria are also very abundant, with generally $10^{9}$ cells per $\mathrm{mL}$ of sediment (Pascal et al. 2009), their diversity and activity remain largely uncharacterized (Gontang et al. 2007). The bacterial communities depend on the depth of sediment layers, and Gammaproteobacteria might be highly predominant (almost $90 \%$ ) in surface layers (Urakawa et al. 2000).

Within mudflat biofilms, multiple interactions such as synergy, competition, or defense occur between microalgae and prokaryotes. Although these interactions are recognized as essential to the biogeochemistry of marine 
ecosystems (Amin et al. 2012), their study is limited. There is a strong correlation between diatom and bacterial abundances (Cammen 1991; van Duyl et al. 1999; Hamels et al. 2001). The presence of bacteria closely associated to diatom cells (referred to as "satellite" bacteria by Schäfer et al. 2002 ) seems essential for some diatom strains to their optimal growth in nature as well as in laboratory cultures (Bruckner et al. 2008, 2011; Amin et al. 2012). Diatom cell aggregation is also enhanced in the presence of bacteria (Bruckner et al. 2008; Lubarsky et al. 2010; Gärdes et al. 2011). Bruckner et al. (2008) and Windler et al. (2015) showed that bacteria can stimulate diatom biofilm formation, as biofilm formation was directly induced by the cell-free spent medium of bacteria, making modification of the diatom metabolism most likely. It has been shown that the carbon photosynthetically assimilated by diatoms is transferred into bacteria in few hours, indicating a rapid use of labile carbon sources, likely including EPS (Middelburg et al. 2000 ; Goto et al. 2001; Cook et al. 2007; Bellinger et al. 2009). To remain within the "phycosphere" where their growth is stimulated by algal EPS (Bell and Mitchell 1972), bacteria often need to attach to the surface of diatom cells. Mechanisms underlying attachment remain unclear, but they likely involve extracellular molecules such as polysaccharides and/or proteins that are also released by bacteria themselves (Amin et al. 2012). EPS are thus crucial intermediaries between bacteria and diatoms. However, interactions between diatoms and bacteria are not always beneficial: Mmany diatoms have defense mechanisms against unwanted and/or algicidal bacteria (Amin et al. 2012 ). They secrete fatty acids, esters, and polyunsaturated aldehydes that can act as antibacterial compounds and influence the bacterial community structure (Lebeau and Robert 2003; Ribalet et al. 2008). However, some diatom-associated bacteria were shown to be resistant to bioactive polyunsaturated aldehydes, suggesting that satellite bacteria may have developed resistance to toxic molecules released by diatoms (Ribalet et al. 2008 ). To our knowledge, nothing is known about the effect of molecules excreted by diatoms in their immediate surroundings on the bacterial biofilm formation.

We previously selected three bacterial strains from intertidal mudflat biofilms of the French Atlantic coast that were able to attach to different surfaces and build biofilms with specific 3D structures (Doghri et al. 2015). These strains are appropriate models for deciphering the colonization of surfaces and the interactions between microorganisms in marine biofilms. Such knowledge is essential to the better understanding of biofouling which causes various and 
costly damages to maritime human activities and industries. Here, we investigated the specific effects of diatom organic EPS on the formation of bacterial biofilms. A $N$. phyllepta isolate was selected since this species is one of the most abundant in temperate intertidal mudflats. To avoid the presence of EPS secreted by satellite bacteria, we axenized N. phyllepta prior to examine the effects of different EPS fractions on the bacterial models.

\section{Materials and methods}

\section{Diatom and bacterial strain isolation and culture}

Benthic diatom Navicula phyllepta Kützing (Culture Collection Yerseke, CCY9804) cells were grown in batch cultures at $20{ }^{\circ} \mathrm{C}$ in sterile artificial $\mathrm{F} / 2$ seawater medium (Tropic Marin salt, Guillard and Ryther 1962) with a light intensity of $75 \mu \mathrm{mol}$ photons $\mathrm{m}^{-2} \mathrm{~s}^{-1}$ and a 16-h light/8-h dark photoperiod (white fluorescent tubes, L58W/840, Osram, Germany). Diatom cultures were started with a concentration of $0.3 \mu \mathrm{g}$ chlorophyll $a(\mathrm{Chl} a) \mathrm{mL}^{-1}$ using a Chl $a$ spectrophotometric quantification (Jeffrey and Humphrey 1975). Specific growth rates, $\mu$ (day ${ }^{-1}$ ), were calculated from regression of the natural logarithm of the Chl $a\left(\mathrm{mg} \mathrm{mL}^{-1}\right)$ during their exponential growth phase. During its growth, N. phyllepta forms a biofilm in the flask bottom that can be visually observed.

Benthic bacteria We used strains Flavobacterium sp. II2003, Roseobacter sp. IV3009, and Shewanella sp. IV3014. They were isolated from the intertidal temperate mudflat biofilm of the Marennes-Oléron Bay (French Atlantic coast) and selected for their ability to form biofilms on different surfaces, under static and dynamic conditions (Doghri et al. 2015). Strains were conserved as frozen stocks with $25 \%$ glycerol at $-80{ }^{\circ} \mathrm{C}$. For all tests, the bacteria were grown at $22{ }^{\circ} \mathrm{C}$ in Zobell broth (Bio-Rad pastone $4 \mathrm{~g} \mathrm{~L}^{-1}$; Bio-Rad yeast extract $1 \mathrm{~g} \mathrm{~L}^{-1}$; sea salts Sigma $30 \mathrm{~g} \mathrm{~L}^{-1}$ ) supplemented with $\operatorname{agar}\left(12 \mathrm{~g} \mathrm{~L}^{-1}\right.$ Biokar) for solid medium.

\section{Axenization of $N$. phyllepta}

Different axenization strategies were investigated, combining mechanical cell separation and antibiotic treatments (Fig. 1 and Table 1). Based on Shishlyannikov et al. (2011), two pretreatments of the diatom suspensions were tested and compared with a non-pretreated control (Fig. 1, "Physicochemical pretreatments"). The suspensions, pretreated with or without Triton $\mathrm{X}-100$, were filtered through a $5-\mu \mathrm{m}$ polycarbonate membrane (Millipore, 
USA) put on a Whatman membrane by using a manual filtration unit (Sartorius, Germany). Diatom cells were then washed with artificial seawater and transferred to F/2 medium. Different antibiotics, alone or in combination (Table 1), were added to the pretreated or the control suspensions, and diatom cells were grown as described above, with soft shaking at regular time intervals (Fig. 1, "Antibiotic treatments"). The final concentrations of the tested antibiotics are described in Table 1. Diatom cells were then harvested by filtration, rapidly washed with culture medium, and resuspended in F/2 medium. The degree of axenization of diatom cell suspensions was then immediately checked by (i) bacterial counting with epifluorescence microscopy after 4'6-diamidino-2-phenylindole (DAPI) staining and (ii) counting the number of colony forming units (CFU—culturable bacteria) after plating diatom cell suspensions on Zobell agar (Fig. 1, "Checking"). For the microscope counting, diatom cell samples were fixed in formaldehyde (final concentration $2 \%$ ) and diluted in di-sodium pyrophosphate $10 \mathrm{mM}$ with $0.1 \%$ of Tween 80 in order to enhance detachment of bacteria from the diatoms (Lavergne et al. 2014). After incubation for $30 \mathrm{~min}$ at $4{ }^{\circ} \mathrm{C}$, samples were stained with DAPI $\left(1 \mathrm{mg} \mathrm{L}^{-1}\right)$ for $15 \mathrm{~min}$ and filtered through a $0.2-\mu \mathrm{m}$ polycarbonate membrane (Nuclepore Track-Etch Membrane, Whatman Schleicher \& Schuell, USA). The membranes were mounted on a glass slide in a non-fluorescent oil drop, and bacterial cells were counted with an epifluorescence microscope (Leica DMRB, mercury steam light, magnification $\times 1000$, filter UV A Leica) on an average of five fields of $0.0415 \mathrm{~mm}^{2}$ each.

\section{Fig. 1}

Key steps of the axenization protocol of the N. phyllepta diatom culture. Protocol finally selected (bold arrows) 


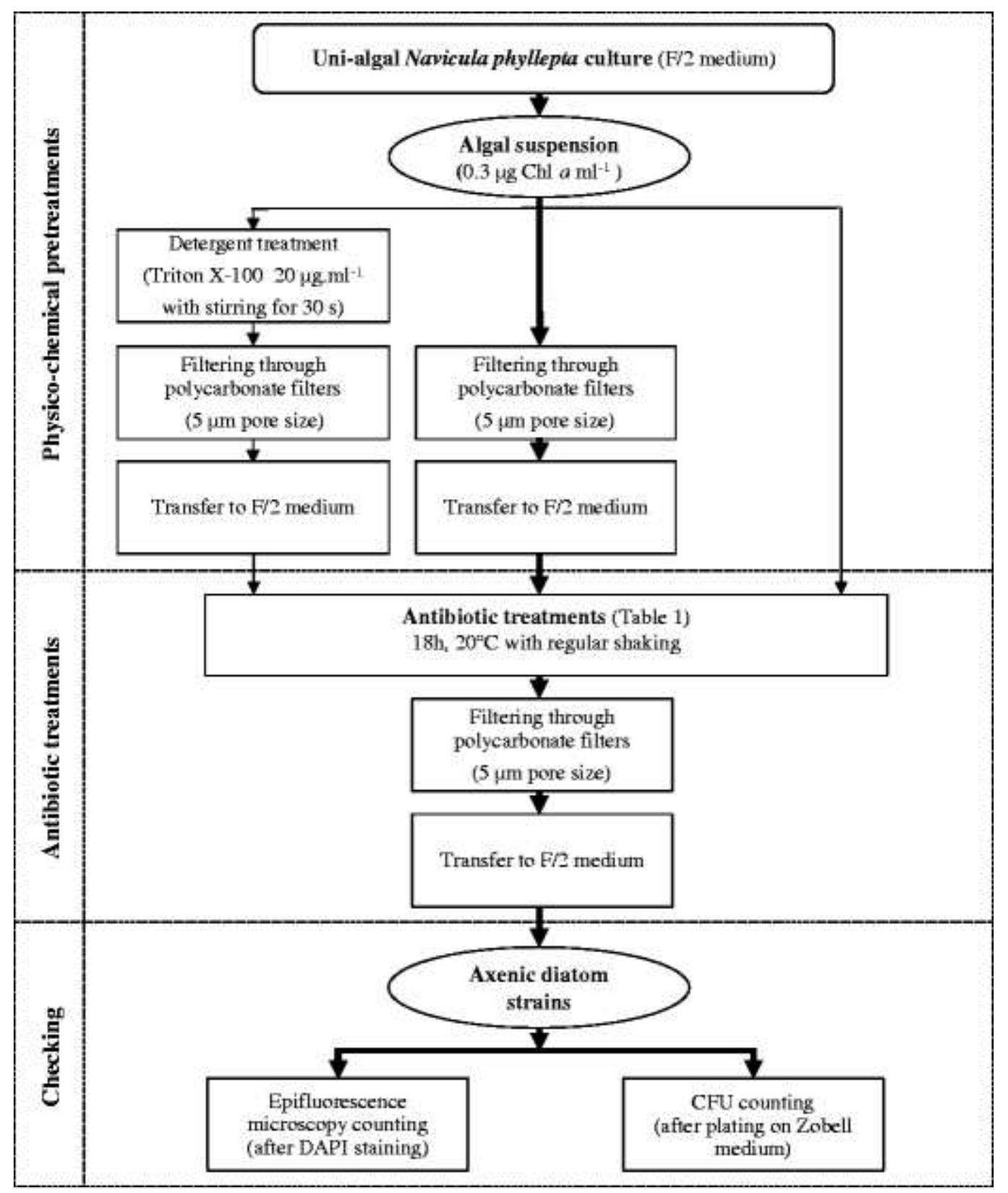

\section{Table 1}

Antibiotics tested alone or in combination for the axenization of the N. phyllepta cultures

\begin{tabular}{|l|l|l|}
\hline \multicolumn{1}{|c|}{ Antibiotics } & \multicolumn{1}{|c|}{ Solvent(s) (\%/\%) } & Final concentration $\left(\boldsymbol{\mu g ~ m ~ ~ ^ { - 1 } )}\right.$ \\
\hline $\mathrm{Ap}$ & Ethanol/water $(50 / 50)$ & 100 \\
\hline $\mathrm{Tc}$ & Ethanol/water $(50 / 50)$ & 50 \\
\hline $\mathrm{Sm}$ & Water & 100 \\
\hline $\mathrm{Km}$ & Water & 50 \\
\hline $\mathrm{Km}+\mathrm{Sm}$ & Water & $100 / 100$ \\
\hline
\end{tabular}

Ap ampicillin, $T c$ tetracycline, $S m$ streptomycin, $K m$ kanamycin, Cip ciprofloxacin, Ipm imipenem 


\begin{tabular}{|l|l|l|}
\hline \multicolumn{1}{|c|}{ Antibiotics } & \multicolumn{1}{|c|}{ Solvent(s) (\%/\%) } & Final concentration $\left(\boldsymbol{\mu g ~ m ~} \mathbf{~ L}^{-\mathbf{1}}\right)$ \\
\hline $\mathrm{Ap}+\mathrm{Sm}$ & Ethanol/water $(25 / 75)$ & $100 / 100$ \\
\hline $\mathrm{Ap}+\mathrm{Tc}+\mathrm{Km}$ & Ethanol/water $(25 / 75)$ & $100 / 50 / 30$ \\
\hline $\mathrm{Ap}+\mathrm{Tc}+\mathrm{Sm}+\mathrm{Km}$ & Ethanol/water $(25 / 75)$ & $100 / 50 / 100 / 30$ \\
\hline $\mathrm{Cip}$ & Water & 5 \\
\hline $\mathrm{Ipm}$ & Water & 98 \\
\hline
\end{tabular}

Ap ampicillin, $T c$ tetracycline, $S m$ streptomycin, $K m$ kanamycin, Cip ciprofloxacin, Ipm imipenem

\section{Extraction of EPS from axenic cultures of $N$. phyllepta}

The detailed protocol was adapted from Takahashi et al. (2009) and is summarized in Fig. 2. The axenic N. phyllepta suspension was cultured during 6 days $\left(\mathrm{D}_{6}\right.$, middle of the exponential phase, $\left.1.16 \mu \mathrm{g} \mathrm{Chl} a \mathrm{~mL}^{-1}\right)$ and 12 days $\left(\mathrm{D}_{12}\right.$, stationary phase, $\left.1.24 \mu \mathrm{g} \mathrm{Chl} a \mathrm{~mL}^{-1}\right)$ in order to collect the colloidal and bound EPS. $\mathrm{D}_{6}$ and $\mathrm{D}_{12}$ samples were centrifuged to harvest the supernatants containing the colloidal EPS fraction. To extract EPS bound to the diatom cells, the pellets were resuspended in F/2 medium containing activated cation exchange resin (Dowex Marathon $\mathrm{C} \mathrm{Na}^{+}$, Sigma-Aldrich, USA) and left under gentle shaking. After centrifugation, both colloidal and bound EPS fractions were filtered (Millipore PVDF filters, USA) and lyophilized. The dried fractions were resuspended in $1 \mathrm{~mL}$ ultra-pure water. The salt excess was removed by dialysis (molecular cutoff of $1000 \mathrm{Da}$, Spectrum Labs, USA) against ultra-pure water, and EPS samples were then stored at $-80{ }^{\circ} \mathrm{C}$ until further use.

Fig. 2

Protocol for the extraction of EPS from axenic N. phyllepta cultures 


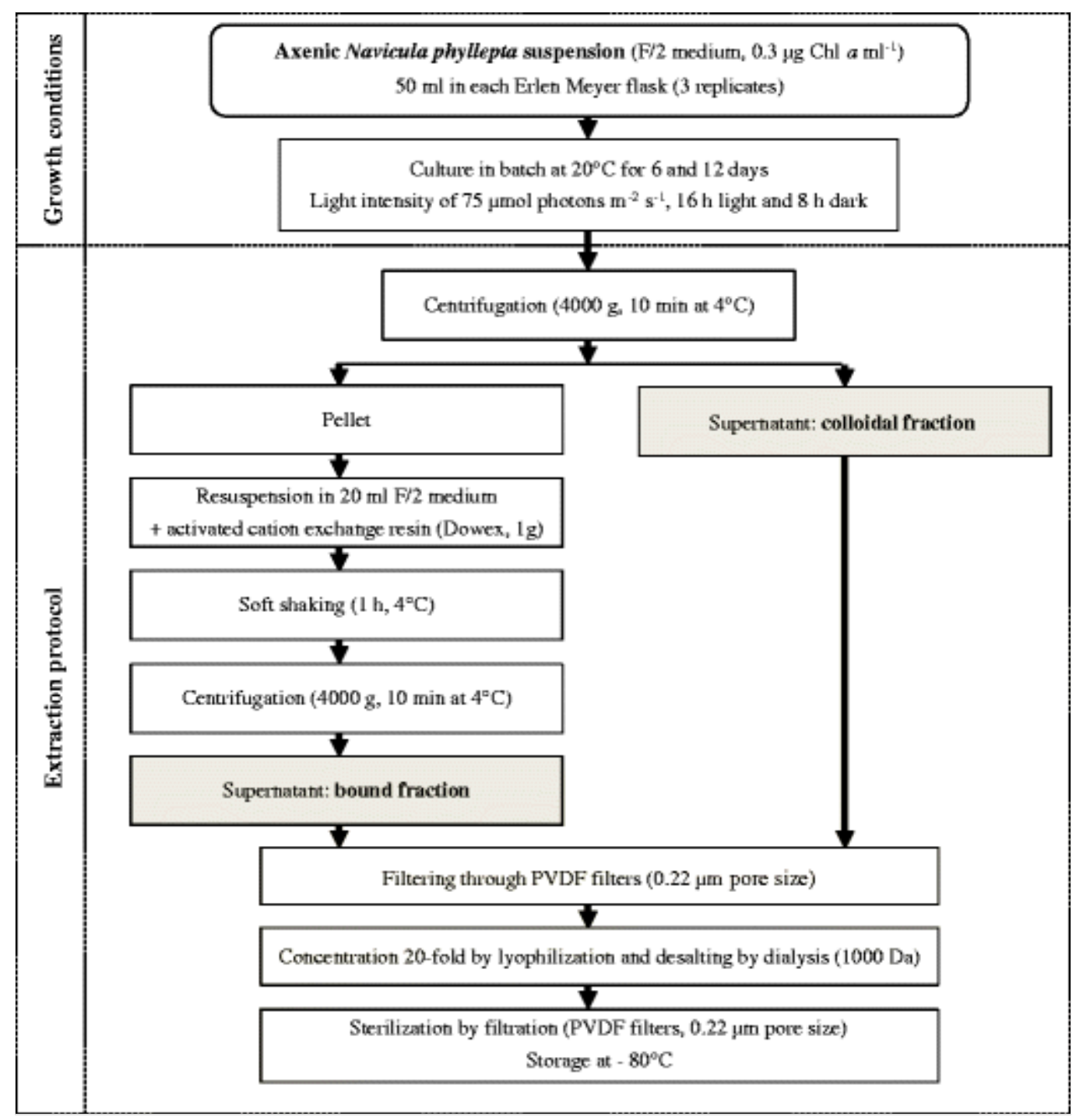

\section{Antibacterial assay}

Antibacterial (i.e., bactericidal or bacteriostatic) activity of EPS was tested by using the agar well diffusion assay previously described by Sablé et al. (2000). Sterile glass rings (4-mm inside diameter) were placed on solid nutrient plates $\left(15 \mathrm{~mL}\right.$ of Zobell agar inoculated with $10^{7}$ of the target bacteria) and filled with $30 \mu \mathrm{L}$ of the EPS $20 \times$ samples to be tested. The plates were incubated at $22{ }^{\circ} \mathrm{C}$ for $48 \mathrm{~h}$ to allow bacterial growth and EPS diffusion. The presence of a halo around the glass cylinder indicates an inhibition of bacterial growth if the halo is clear (without cell growth) or eventually a stimulation if the halo is denser than the remaining plate (with cell growth).

\section{Effect of the diatom EPS on bacterial biofilm formation}

Microtiter plate assay: static conditions According to Pitts et al. (2003), the EPS fractions were mixed to bacterial suspensions during the adhesion step. After overnight growth (Zobell broth, shaking at $150 \mathrm{rpm}$, 
$\left.22{ }^{\circ} \mathrm{C}\right)$ and harvesting by centrifugation $(7000 \times g, 10 \mathrm{~min})$, bacteria were resuspended in artificial seawater (for the control) or in EPS $20 \times$ fractions to a final optical density at $600 \mathrm{~nm}\left(\mathrm{OD}_{600}\right)$ of 0.25 . Of the resulting suspensions $\left(10^{8} \mathrm{CFU} \mathrm{mL}^{-1}\right), 150 \mu \mathrm{L}$ was then loaded per well of a 96-well microtiter plate (MICROTEST 96, Falcon, USA). After a bacterial attachment step of $2 \mathrm{~h}$ at $22{ }^{\circ} \mathrm{C}$, the wells were gently washed three times with artificial seawater, and $150 \mu \mathrm{L}$ Zobell medium were added to each well. After incubation at $22{ }^{\circ} \mathrm{C}$ for $24 \mathrm{~h}$, the bacterial biofilms were washed three times with artificial seawater, stained with a $0.8 \%$ crystal violet solution for $20 \mathrm{~min}$, and rinsed with ultra-pure water until the wash liquid was clear (10 times on average). Crystal violet was then eluted from attached bacteria with $96 \%$ ethanol $\left(150 \mu \mathrm{L}^{-1} \mathrm{well}^{-1}\right)$, and the absorbance was measured with a plate reader at $595 \mathrm{~nm}$ (FLUOstar Omega, BMG Labtech, Germany) to quantify the biofilms.

Flow cell assay: dynamic conditions Bacterial biofilms were grown on glass slides in continuous culture three-channel flow cells (channel dimensions 1 by 4 by $40 \mathrm{~mm}$, Technical University of Denmark Systems Biology, Denmark) as described by Pamp et al. (2009). Flow cells were inoculated with 24-h old bacterial cultures diluted in artificial seawater (for the control) or in EPS $20 \times$ fractions to a final $\mathrm{OD}_{600}$ of 0.1 . Bacteria were allowed to attach to the glass slide during $2 \mathrm{~h}$ at $22{ }^{\circ} \mathrm{C}$ without medium flow. Channels were washed to remove non-attached bacteria by applying a flow of artificial seawater for $15 \mathrm{~min}$ at a rate of $2 \mathrm{~mL} \mathrm{~h}^{-1}$, and biofilm growth was allowed for $24 \mathrm{~h}$ at $22{ }^{\circ} \mathrm{C}$ under a constant flow $\left(2 \mathrm{~mL} \mathrm{~h}^{-1}\right)$ of Zobell medium. The biofilms were then stained with $5 \mu \mathrm{M}$ Syto 61 Red and observed by confocal laser scanning microscopy (CLSM) using a TCS-SP2 system (Leica Microsystems, Germany). The biofilm stacks were analyzed with the COMSTAT software (developed in MATLAB, Heydorn et al. 2000) to estimate the maximal and the average thicknesses $(\mu \mathrm{m})$ as well as the biovolume $\left(\mu \mathrm{m}^{3} \mu \mathrm{m}^{-2}\right)$ of each biofilm.

\section{Biochemical assays and characterization of the diatom active EPS fraction}

Proteins assays were carried out with a bicinchoninic acid protein assay kit (Sigma-Aldrich, USA), using bovine serum albumin as a standard (Smith et al. 1985 ). The sugar content was determined using the phenol-sulfuric acid assay, using glucose as standard (Dubois et al. 1956). To elucidate the biochemical nature of the active component(s) of diatom EPS $20 \times$ fractions, 
different treatments were performed to digest proteins, lipids, nucleic acids, and saccharides. Proteinase $\mathrm{K}$ or Pronase $\mathrm{E}$ was added to a final concentration of $1 \mathrm{mg} \mathrm{mL}^{-1}$, and the reaction was incubated for $1 \mathrm{~h}$ at $37^{\circ} \mathrm{C}$. Lipase acrylic resin form was used at a final concentration of $2 \mathrm{mg} \mathrm{mL}^{-1}$, and the reaction was incubated for $48 \mathrm{~h}$ under shaking at $37{ }^{\circ} \mathrm{C}$. DNaseI $\left(100 \mu \mathrm{g} \mathrm{mL}{ }^{-1}\right)$ or RNaseA $\left(25 \mu \mathrm{g} \mathrm{mL}^{-1}\right)$ was added for $12 \mathrm{~h}$ at $37^{\circ} \mathrm{C}$. $\mathrm{NaIO}_{4}$ was used to hydrolyze saccharides by cleaving the $\mathrm{C}-\mathrm{C}$ bonds and by oxidizing the carbon of vicinal hydroxyl groups (Mack et al. 1996; Bendaoud et al. 2011). We improved the classical treatment $\left(20 \mathrm{mM} \mathrm{NaIO}_{4}\right.$, incubation for $12 \mathrm{~h}$ at $\left.37{ }^{\circ} \mathrm{C}\right)$ by adding a neutralization step of $\mathrm{NaIO}_{4}$ with ethylene glycol (1:100) (Babor et al. 1973 ) for $2 \mathrm{~h}$ at $37^{\circ} \mathrm{C}$ followed by a final dialysis step (1000 Da). Each treated EPS fraction was mixed to bacterial suspension during the adhesion step, and a microtiter plate assay was performed as previously described.

\section{Statistical analyses}

All values presented in the "Results" part are the average of three independent experiments. In order to analyze differences between a sample and the corresponding control, Student's $t$ tests were performed. ANOVA tests gave the same results.

\section{Results}

\section{Axenization of the N. phyllepta diatom from associated bacteria}

The uni-algal $N$. phyllepta cultures were non-axenic, and the initial suspension $\left(0.3 \mu \mathrm{g} \mathrm{Chl} a \mathrm{~mL}^{-1}\right)$ contained in average about $10^{6}$ bacteria $\mathrm{mL}^{-1}$ (Table 2). In order to test the effect of EPS specifically secreted by $N$. phyllepta and to avoid interference with EPS synthesized by the bacteria associated with diatom cells, it was crucial to remove bacteria present in these cultures. Different antibiotic treatments as well as pretreatments potentially increasing the effectiveness of antibiotics were then investigated (Fig. 1). While the detergent treatment associated with the filtration reduced the bacterial load by $40 \%$ (Table 2 ), it considerably affected the viability of the diatom cells ( $\mathrm{Chl} a$ in cultures decreased by more than $50 \%$ ) and the ability of $N$. phyllepta to form a biofilm (visual observation of a brown layer of diatom cells in the flask bottom). The filtration without detergent treatment reduced the bacterial contamination by up to $26 \%$ (Table 2) without affecting viability and culture aspect of diatoms. This pretreatment was therefore chosen. After validation of this step, different antibiotics (ampicillin [Ap], 
ciprofloxacin [Cip], imipenem [Ipm], kanamycin [Km], streptomycin [Sm], and tetracycline $[\mathrm{Tc}]$ ) were tested, alone or in combination. The treatments including Ap, Tc, or Ipm were quickly discarded owing to the modification of the visual aspect (i.e., pigmentation), the ability to form a biofilm, and the growth rate of the diatom cultures. The results obtained with the most promising antibiotics are shown in Table 2. Cip and Sm treatments reduced the bacterial contamination by $94 \%$ according to microscope counting and by 60 and $73 \%$ according to agar medium plating, respectively. Km treatment also reduced significantly the bacterial contamination, in particular the bacteria growing on agar medium. Nevertheless, the strongest effect was exerted by the $\mathrm{Km}+\mathrm{Sm}$ mix which completely removed bacterial contamination.

\section{Table 2}

Enumeration of bacteria associated with $N$. phyllepta before and after physico-chemical and antibiotic treatments

\begin{tabular}{|c|c|c|}
\hline & 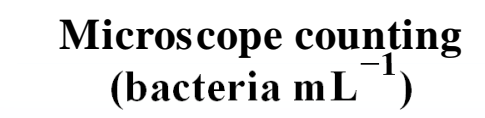 & $\begin{array}{c}\text { Counting by plating on agar } \\
\left.\text { medium (CFU mL }{ }^{-1}\right)\end{array}$ \\
\hline \multirow[t]{2}{*}{$\begin{array}{c}\text { Initial algal } \\
\text { suspension without } \\
\text { treatment }\end{array}$} & $1.1 \times 10^{6} \pm 1.4 \times 10^{4}$ & $1.9 \times 10^{5} \pm 3.1 \times 10^{4}$ \\
\hline & $1.9 \times 10^{5} \pm 3.1 \times 10^{4}$ & \\
\hline \multicolumn{3}{|c|}{ Physico-chemical pretreatment } \\
\hline Filtering & $8.5 \times 10^{5} \pm 10^{4}$ & $1.4 \times 10^{5} \pm 2.7 \times 10^{4}$ \\
\hline Detergent + filtering & $6.8 \times 10^{5} \pm 1.3 \times 10^{4}$ & $1.1 \times 10^{5} \pm 2.4 \times 10^{4}$ \\
\hline \multicolumn{3}{|c|}{ Antibiotic treatment after filtering ${ }^{\mathrm{a}}$} \\
\hline Cip & $6.5 \times 10^{4} \pm 1.1 \times 10^{4}$ & $7.5 \times 10^{4} \pm 7.8 \times 10^{3}$ \\
\hline $\mathrm{Sm}$ & $6.2 \times 10^{4} \pm 6.1 \times 10^{3}$ & $5.1 \times 10^{4} \pm 10^{2}$ \\
\hline $\mathrm{Km}$ & $5.1 \times 10^{4} \pm 1.1 \times 10^{4}$ & $4.0 \times 10^{2} \pm 7$ \\
\hline $\mathrm{Km}+\mathrm{Sm}$ & No bacterium detected & No bacterium detected \\
\hline \multicolumn{3}{|c|}{ Cip ciprofloxacin, $S m$ streptomycin, $K m$ kanamycin } \\
\hline \multicolumn{3}{|c|}{${ }^{\mathrm{a}}$ Antibiotics not toxic for $N$. phyllepta } \\
\hline
\end{tabular}

To summarize the selected protocol of axenization, the algal suspension was first filtered, treated with $\mathrm{Km}$ and $\mathrm{Sm}$ for $18 \mathrm{~h}$, again filtered, and transferred 
in new culture medium. The growth rate of the obtained axenic diatom cultures was $\sim 1.2$ day $^{-1}$, similar to untreated diatom cultures (data not shown).

\section{Effects of the N. phyllepta EPS fractions on bacterial biofilm formation}

In order to observe biological effects, $N$. phyllepta EPS were concentrated. Based on the EPS protein and saccharide contents, a $20 \times$ concentration was chosen, to reach concentrations slightly higher than what was observed in the intertidal mudflats where N. phyllepta is the major diatom (Pierre et al. 2012).

Antibacterial assays, performed with the agar well diffusion techniques, did not exhibit any clear halo characteristic of inhibition of bacterial growth. These experiments then showed that no EPS fractions from diatom cultures had a bactericidal or bacteriostatic activity against the three tested marine bacterial strains: Flavobacterium sp. II2003, Roseobacter sp. IV3009, and Shewanella sp. IV3014. Moreover, no stimulation of the bacterial growth (halo denser than the remaining plate) was observed around the deposit of EPS fractions.

We then examined whether EPS fractions affected biofilm formation. In static conditions (on polystyrene surface, microtiter plate assay, quantification of biofilms by spectrophotometry), the $\mathrm{D}_{6}$ colloidal and bound EPS fractions (Fig. 3a), as well as the $\mathrm{D}_{12}$ colloidal EPS fraction (Fig. 3b), did not show any significant activity on bacterial biofilm formation. On the contrary, the $\mathrm{D}_{12}$ bound EPS fraction showed significant effects: Ccompared with the not treated control biofilms, the biofilms treated with this EPS fraction were reduced by more than $40 \%$ for Flavobacterium sp. II2003 $(t=-13.63$; $p<0.01)$ and were increased by more than $30 \%$ for Roseobacter sp. IV3009 $(t=6.97 ; p<0.05)$ and Shewanella sp. IV3014 $(t=11.99, p<0.01)$ (Fig. $3 \mathrm{~b})$. In a second set of experiments, the activity of the $\mathrm{D}_{12}$ bound EPS fraction on bacterial biofilm formation was further tested by growing the biofilms under dynamic conditions (on glass surface, flow cell assay, observation of biofilms by confocal laser scanning microscopy). The main aim of this set of experiments was to confirm EPS effects obtained under static conditions. The antibiofilm activity against Flavobacterium sp. II2003 was also observed in the second conditions. Compared with the untreated sample, the treated biofilm was very thin: $-76 \%$ of the biovolume $(t=-6.82$, 
$p<0.01),-47 \%$ of the average thickness $(t=-5.89, p<0.01)$, and $-60 \%$ of the maximal thickness of the biofilm $(t=-13.20, p<0.001)$, and it lost its mushroom-like 3D structures (Fig. 4a). Under dynamic conditions, the Roseobacter $\mathrm{sp}$. IV3009 biofilm seemed to be still stimulated compared with the untreated sample, but this positive effect of $\mathrm{D}_{12}$ bound EPS was not significant anymore $(t=1.41, p=0.24$ for the biovolume, $t=1.78, p=0.25$ for the maximum thickness, and $t=2.28, p=0.09$ for the average thickness) (Fig. $4 \mathrm{~b}$ ). However, the stimulating effect of $\mathrm{D}_{12}$ bound EPS was maintained for Shewanella sp. IV3014 (Fig. 4c): Aan increased biovolume ( $+40 \%$, with $t=3.59, p<0.05)$ and increased average thickness (+43\%, with $t=4.64$, $p<0.01)$ and maximal thickness $(+37 \%$, with $t=3.62, p<0.05)$ were observed, without modification of the hairy architecture compared with the control biofilm. The results obtained under static and dynamic conditions were thus consistent for Flavobacterium sp. II2003 and Shewanella sp. IV3014.

\section{Fig. 3}

Effect of EPS fractions from axenic $N$. phyllepta cultures on bacterial biofilm formation in static conditions. Flavobacterium sp. II2003, Roseobacter sp. IV3009, and Shewanella sp. IV3014 were mixed during the adhesion step in microplates with the EPS fractions collected after $6\left(\mathrm{D}_{6}\right)$ or $12\left(\mathrm{D}_{12}\right)$ days of the $N$. phyllepta growth. Biofilms were stained with crystal violet and quantified by measuring absorbance at $595 \mathrm{~nm}$. a $\mathrm{D}_{6}$ EPS fractions and $\mathbf{b} \mathrm{D}_{12}$ EPS fractions. Untreated control: bacterial biofilm without any diatom EPS fraction. The data represent mean values \pm SD of three replicates. Each treated biofilm was compared with the corresponding untreated control biofilm. ${ }^{*} p<0.05$ or ${ }^{* *} p<0.01$, significant differences, only observed with $\mathrm{D}_{12}$ bound EPS fractions $(\mathbf{b})$ 
a

- Treated with colloidal EPS fraction $D_{6}$

$\square$ Treated with bound EPS fraction $D_{\mathscr{G}}$

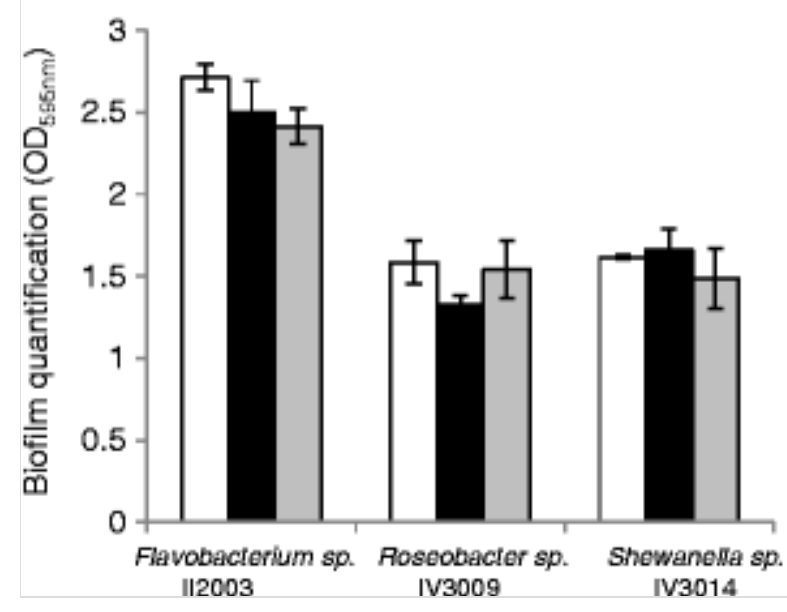

b

口Untreated control biofilm

- Treated with colloidal EPS fraction $D_{12}$

$\square$ Treated with bound EPS fraction $D_{12}$

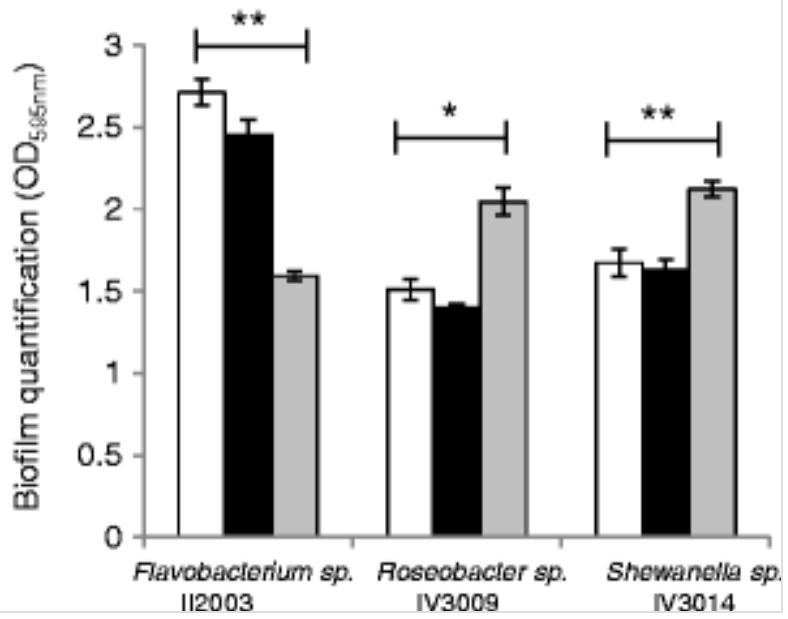

Fig. 4

Effect of EPS bound fraction $\mathrm{D}_{12}$ from axenic $N$. phyllepta cultures on bacterial biofilm formation in dynamic conditions. Biofilms of Flavobacterium sp. II2003 (a), Roseobacter sp. IV3009, (b) and Shewanella sp. IV3014 (c). 3D images of the biofilms (top and side views) are shown on the right (bars $=67.3 \mu \mathrm{m}$ ) and the corresponding COMSTAT analysis output on the left. Untreated control biofilm: bacterial biofilm without diatom EPS fraction. The data represent mean values \pm SD of three replicates 

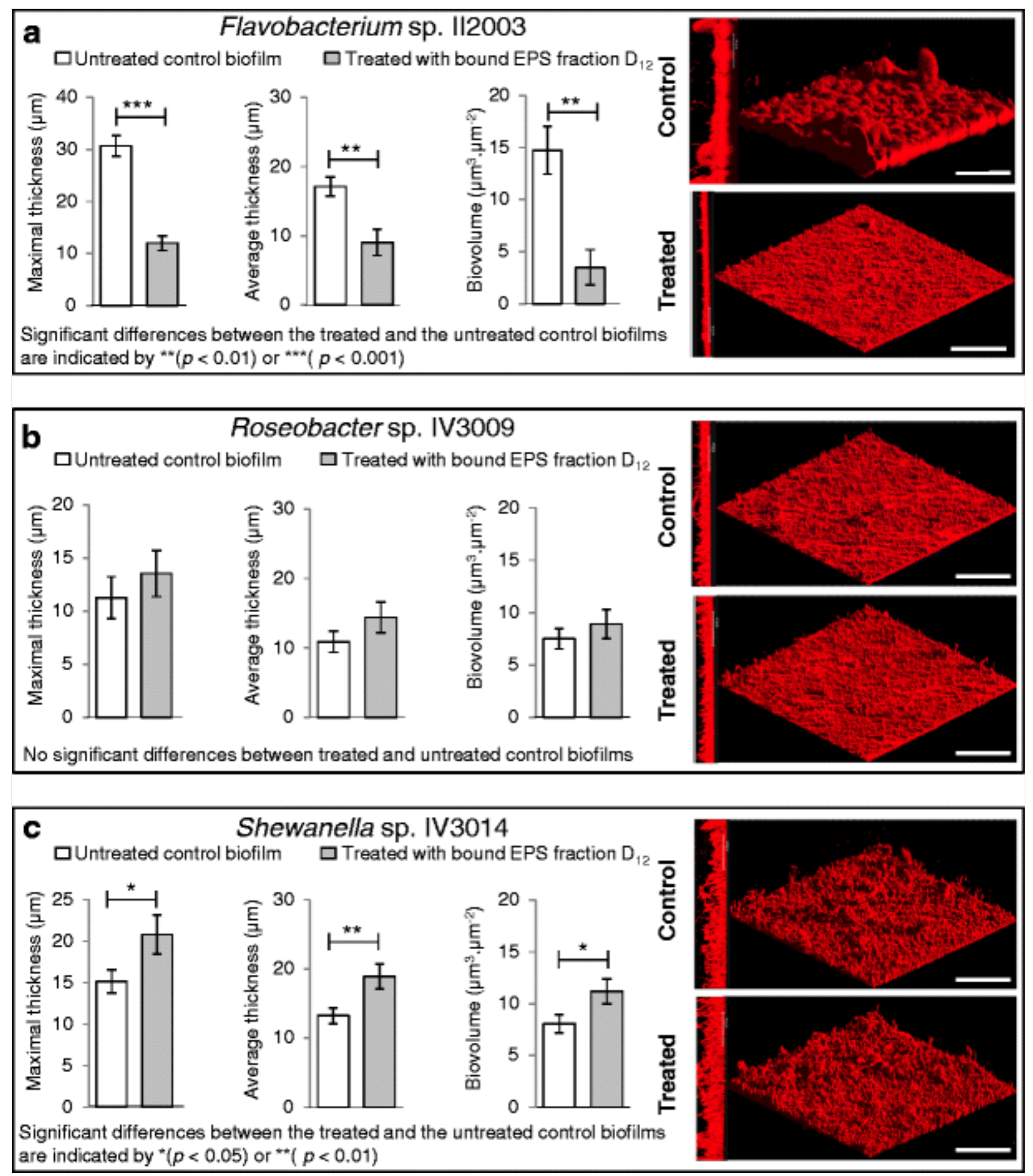

\section{Biochemical characterization of the N. phyllepta active EPS fraction}

The carbohydrate and protein contents of all EPS fractions were quantified (Table 3 ), in order to compare the active and inactive fractions. It is noticeable that carbohydrate and protein quantities were higher in $\mathrm{D}_{12}$ than in $\mathrm{D}_{6}$ fractions. The measure of the chlorophyll content of the cultures allowed us to evaluate the number of diatoms and then to show that the quantities of carbohydrates and proteins per cell were higher in the $\mathrm{D}_{12}$ fractions than in the $\mathrm{D}_{6}$ fraction. Moreover, the carbohydrate content was higher than the protein content in all fractions, and the active fraction $\left(\mathrm{D}_{12}\right.$ bound EPS) was 
the most concentrated in sugars. Navicula phyllepta $\mathrm{D}_{12}$ bound EPS fraction was further analyzed. It was submitted to different treatments to gain information on the chemical nature of the putative active compounds (Fig. 5 ). Neither proteases nor lipase nor nuclease treatments significantly affected the activity of the $\mathrm{D}_{12}$ bound EPS fraction. Only the $\mathrm{NaIO}_{4}$ treatment significantly reduced the antibiofilm activity of the $\mathrm{D}_{12}$ bound EPS fraction, by $90 \%(t=18.53, p<0.001)$, against Flavobacterium sp. II2003, and totally prevented the stimulating activity in Roseobacter sp. IV3009 ( $t=-13.8$, $p<0.001)$ and Shewanella sp. IV3014 $(t=-39.5, p<0.001)$. $\mathrm{NaIO}_{4}$ very efficiently hydrolyzes saccharides by oxidizing the carbons bearing vicinal hydroxyl groups and cleaving the $\mathrm{C}-\mathrm{C}$ bonds (Mack et al. 1996; Jiang et al. 2011 ). These results indicated that the active compounds of the $D_{12}$ bound EPS fraction were saccharidic molecules.

\section{Table 3}

Determination of protein and carbohydrate contents of the N. phyllepta EPS 20x fractions and estimation of these contents per diatom cell

\begin{tabular}{|c|c|c|c|c|}
\hline & \multicolumn{2}{|c|}{$D_{6}$ EPS fractions } & \multicolumn{2}{|c|}{$D_{12}$ EPS fractions } \\
\hline & Colloidal & Bound & Colloidal & Bound \\
\hline Proteins $\left(\mathrm{mg} \mathrm{L}^{-1}\right)$ & $36.3 \pm 2.9$ & $45.9 \pm 2.3$ & $114.0 \pm 8.7$ & $151.0 \pm 5.4$ \\
\hline Proteins (mg cell ${ }^{-1}$ ) & $6.2 \times 10^{-8}$ & $7.9 \times 10^{-8}$ & $1.8 \times 10^{-7}$ & $2.4 \times 10^{-7}$ \\
\hline Carbohydrates $\left(\mathrm{mg} \mathrm{L}^{-1}\right)$ & $45.0 \pm 3.5$ & $198.0 \pm 9.1$ & $178.0 \pm 6.9$ & $690.0 \pm 2.4$ \\
\hline Carbohydrates (mg cell ${ }^{-1}$ ) & $7.7 \times 10^{-8}$ & $3.4 \times 10^{-7}$ & $2.9 \times 10^{-7}$ & $1.1 \times 10^{-6}$ \\
\hline
\end{tabular}

\section{Fig. 5}

Effect of various treatments on the activity of the N. phyllepta $\mathrm{D}_{12}$ bound EPS. The inhibiting or stimulating effects of the N. phyllepta $\mathrm{D}_{12}$ bound EPS were determined using the microtiter plate assay. Biofilms were stained with crystal violet and quantified by measuring absorbance at $595 \mathrm{~nm}$. The "100\%" values on the $Y$-axis are given to the biofilms grown without EPS fraction (aA). Samples + untreated EPS fraction ( $(\mathbf{B})$ correspond to reference values of the inhibiting or stimulating effects of the $N$. phyllepta EPS on the bacterial biofilm formation. The data represent mean values \pm SD of three replicates. The effect of each treated EPS fraction ( $(\mathbf{C}$ to $\mathbf{h H})$ was compared with the effect of the untreated EPS fraction $(\mathrm{bB})$. Highly significant differences were observed, only between not treated $N$. phyllepta $\mathrm{D}_{12}$ bound EPS and EPS treated with $\mathrm{NaIO}_{4}$. These differences are indicated by $* * *(p<0.001)$ on the upper part of the 
figure. $T$ values are $-18.53,13.8$, and 39.5 for Flavobacterium sp. II2003 (a), Roseobacter sp. IV3009 (b), and Shewanella sp. IV3014 (c), respectively

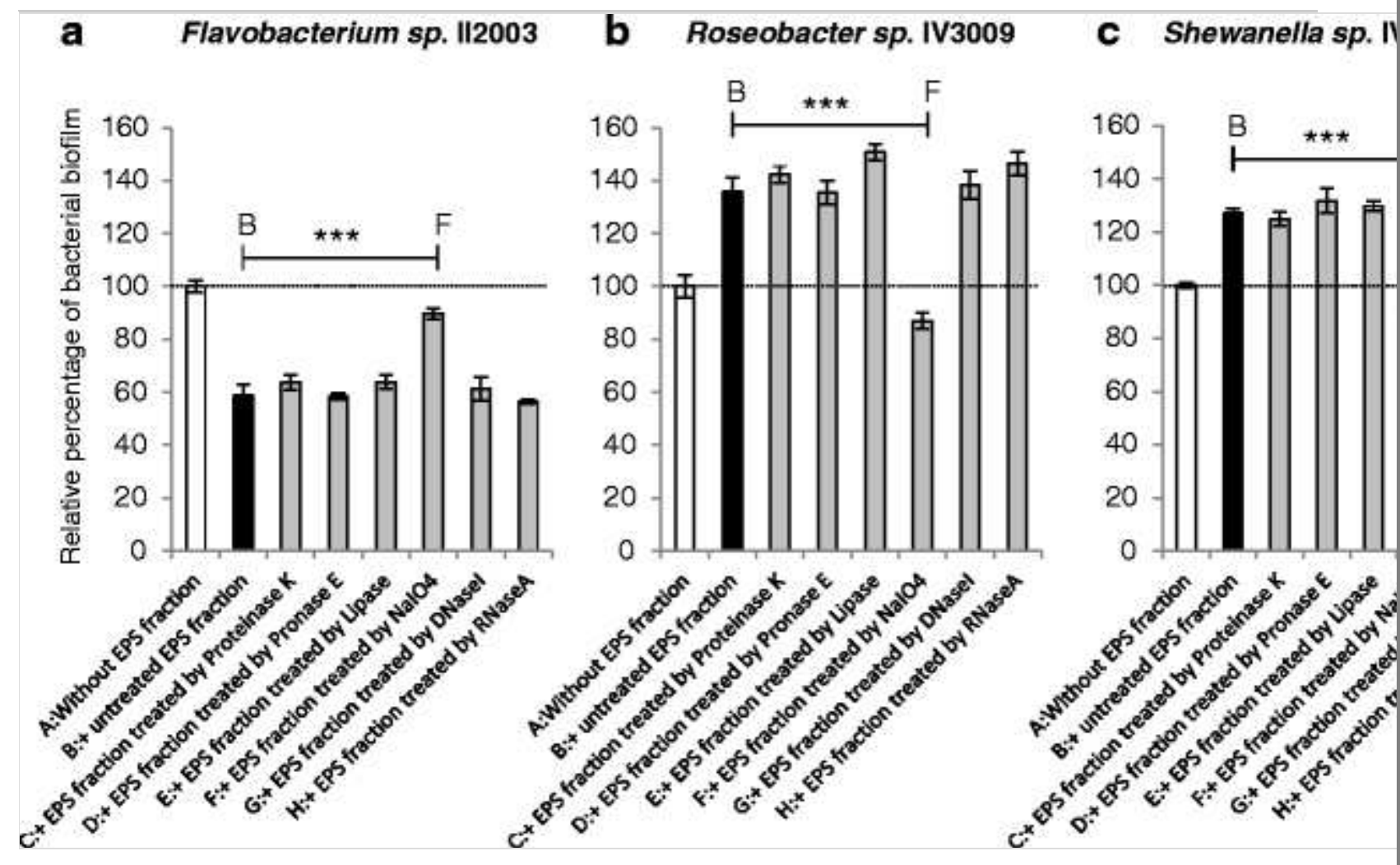

\section{Discussion}

Successful strategy to remove the satellite bacteria from the $N$. phyllepta cultures Axenization of diatom cultures by the removal of bacteria was essential to ascertain that the studied active compounds were indeed produced by $N$. phyllepta and not by its associated bacteria.

Depending on the diatom strain and its growth form, the axenization protocol can be very different (Bruckner and Kroth 2009). In particular, benthic diatoms are often difficult to axenize because of the mucilage that surrounds the cells (Bruckner and Kroth 2009). Moreover, many diatoms in co-culture with bacteria grow denser and faster than their axenic counterparts (Bruckner et al. 2008). We achieved to axenize the intertidal benthic diatom $N$. phyllepta, without changing its main biological properties (aspect, growth, and biofilm formation), thanks to a combination of antibiotics (kanamycin + streptomycin) used after a filtering step. This is in accordance with Bruckner and Kroth (2009) who noticed that for most freshwater benthic diatoms, physical separations and antibiotic treatments have to be combined to fully remove associated bacteria. They succeeded in removing satellite bacteria from some diatom strains with a combination of penicillin G, streptomycin, and chloramphenicol without affecting their biological properties in cultures. 
However, this combination could not be used in our case since chloramphenicol inhibits the growth of Navicula (Khandeparker et al. 2014). Recently, Windler et al. (2012) described a simple protocol for freshwater benthic diatom axenization including treatment of the cultures with the antibiotic imipenem. Here, the imipenem treatment generated a disturbance of N. phyllepta biofilm formation. To optimize our axenization method, diatom cells were treated during the latency phase of the growth curve, during which the bacterial load is low. This approach allowed us to overcome problems due to the excretion of protective substances (such as EPS) by bacteria and diatoms during the growth phase (Flemming and Wingender 2010; Orvain et al. 2014). Additionally, resuspending the cells by shaking at regular intervals enhanced the efficiency of the method by disturbing the diatom-bacterium biofilm formation and thus by decreasing the protection toward antibiotics.

\section{EPS produced by N. phyllepta exhibit activity on bacterial biofilm} formation The main objective of our work was to investigate the effects of the EPS produced by axenic diatom $N$. phyllepta on the ability of three benthic bacterial models to form a biofilm. We worked intentionally with a concentration of EPS slightly higher than in the environment such as intertidal mudflats in order to better highlight biological activities. The examined bacterial strains reacted to one or several molecules secreted by $N$. phyllepta, suggesting that a direct diatom-bacterium contact was not required, as reported before (Windler et al. 2015 ). Navicula phyllepta produced the active molecule(s) when cultivated separately from bacteria, which means that the synthesis and the secretion of these molecules were not induced by bacterial presence and/or activity. In our experimental conditions, the secretome part of $N$. phyllepta active on the early stages of bacterial biofilm formation was the bound EPS fraction harvested during the stationary phase of diatom growth. Its main begotten effects were (i) a strong inhibition (more than $40 \%$ ) of the biofilm formation of Flavobacterium sp. II2003 under both static and dynamic conditions and (ii) a stimulation of the biofilm formation, again under both conditions for Shewanella sp. IV3014 (up to $40 \%$ ) and only under static conditions for Roseobacter sp. IV3009. The results first depend on the bacterial strains and, to a lesser extent, on the experimental approach. In our case, it is likely that the difference in the surface properties between static (polystyrene) and dynamic (glass) conditions may influence early stages of surface colonization and subsequent biofilm formation of the bacterial strains (Dang and Lovell 2000; Jones et al. 2006; Lee et al. 2008). It was therefore essential to investigate different conditions of growth and/or biofilm formation to confirm (or not) the significance of the positive or the negative 
effect of the bound EPS fraction on the bacterial biofilm.

\section{The active N. phyllepta compounds are bound EPS carbohydrates}

The biochemical characterization of the active bound EPS fraction demonstrated that the inhibiting/stimulating activity can be assigned to saccharidic compounds, which were very abundant in the active fraction. In fact, the carbohydrate concentration in both bound and colloidal algal EPS fractions was approximately 4 -fold higher during the stationary phase $\left(\mathrm{D}_{12}\right)$ than during the exponential growth phase $\left(D_{6}\right)$. This is in accordance with Underwood and Paterson (2003) who described that the concentrations of extracellular carbohydrates in the medium significantly increased during the transition from exponential growth to stationary phase for benthic diatoms, including Navicula species, when grown in batch culture. Additionally, the amount of proteins was lower (up to 4.6-fold less for bound EPS) compared with the amount of carbohydrates, which is in agreement with previous reports on Navicula strains (Staats et al. 1999; Underwood and Paterson 2003; Scholz 2014). EPS (colloidal and bound fractions) extracted directly from mudflat microphytobenthic biofilms also predominantly consisted of polysaccharides, and only small quantities of proteins were present (Underwood and Paterson 2003; Pierre et al. 2012).

Potential mode of action of the N. phyllepta EPS on the bacterial biofilm formation In the phycosphere model of Bell and Mitchell (1972), bacterial growth and metabolic activity were proposed to be stimulated by microalgal extracellular substances. Algal organic substances are generally considered as energy and carbon sources for bacteria (Bellinger et al. 2009), and EPS might favor bacterial metabolism by supplying nutrients (Middelburg et al. 2000; Goto et al. 2001; Cook et al. 2007; Bellinger et al. 2009). Although no stimulation of bacterial growth has been observed in solid culture medium, the biofilm formation of Shewanella sp. IV3014 and Roseobacter sp. IV3009 was enhanced by N. phyllepta EPS. Indeed, failing to directly act on cell multiplication, microalgal polysaccharide could act as signaling molecules that modulate the expression of genes involved in biofilm lifestyle of recipient bacteria (Rendueles et al. 2013). Diatom EPS are also assumed to facilitate cell attachment to a surface and to protect cells against desiccation and different environmental stress (Lubarsky et al. 2010; Orvain et al. 2014), thus enhancing the development of associated bacteria biofilms.

In our work, $N$. phyllepta polysaccharides showed also a powerful biofilm inhibition activity on Flavobacterium sp. II2003, without any antibacterial activity, which leads to ascribe the $N$. phyllepta polysaccharide activity as 
specifically antibiofilm. Several studies identified antibiofilm molecules from bacteria, and exopolysaccharides were specifically shown (i) to interfere with bacterial adherence to surfaces and biofilm formation (Valle et al. 2006; Jiang et al. 2011), (ii) to modulate expression of genes (such as curli genes) related to biofilm formation in bacteria (Kim et al. 2009; Rendueles et al. 2013), or (iii) to disrupt established biofilms (Qin et al. 2009; Jiang et al. 2011). However, very few polysaccharides from microalgae were described as negatively impacting bacteria or other microorganism activities, and none of them were studied in the marine context. They are (i) polysaccharides isolated from the Chlorella (green microalga) and Spirulina (cyanobacterium) inhibiting the binding of Helicobacter pylori to gastric mucin in vitro (Loke et al. 2007) and (ii) a sulfated polysaccharide named naviculan and isolated from Navicula directa displaying antiviral activities against herpes simplex and influenza A viruses (Lee et al. 2006). Recently, it has been shown that changes in the composition of carbohydrates produced by the diatom Asterionellopsis glacialis reduced bacterial abundance (da Silva et al. 2016).

As regards to the physico-chemical aspect of biofilm formation, the stimulating or inhibiting effect of microalgal EPS can also be due to modifications of the substratum (abiotic surface) and/or of the bacterial cell surface (Grossart et al. 2006; Rendueles et al. 2013). Studies utilizing culture supernatants or purified polysaccharides as surface coating provide further evidence that microbial polysaccharides modify the wettability and the charge of abiotic surfaces and hence affect the interaction of bacteria with the substratum (Valle et al. 2006; Rendueles et al. 2011). Additionally, polysaccharides are suspected to change the physical properties of gram-negative and gram-positive bacteria cell surfaces such as the cell surface hydrophobicity (Sayem et al. 2011). These properties are essential during the adhesion phase of biofilm formation and the further development of microcolonies (O'Toole et al. 2000).

Interest for the diatoms to modulate the formation of bacterial biofilms and potential biotechnological applications Our experiments with axenic diatom secretomes and different benthic bacterial biofilm models clearly demonstrate that specific interactions between algae and bacteria are instrumental for bacterial biofilm formation. Specific algae-bacteria interactions have largely been neglected so far but are presumably as important as, for instance, nutrient supply and grazing in controlling the development of microphytobenthic biofilms (Grossart et al. 2006). In our work, it is striking that the active diatom bound EPS fraction showed two 
opposite effects on bacterial biofilm formation, depending on the strains. One can hypothesize that $N$. phyllepta would favor some satellite bacteria for its own (or reciprocal) benefit and, conversely, would inhibit attachment of others, useless or detrimental to diatom cells (Amin et al. 2012). Bound EPS might be closely involved into the formation of the extracellular matrix of the microphytobenthic biofilm, facilitate attachment of the cell to a surface, and also improve cell-cell interactions between bacteria and diatoms (Lubarsky et al. 2010; Pierre et al. 2012). It strongly suggests the existence of complex physico-chemical interactions between microorganisms in natural biofilms, especially in our model, i.e., the transitory biofilm forming at the surface of sediment of intertidal mudflats during daily emersion. These interactions could allow a process of selection/adaptation to changing environmental conditions, and populations able to co-exist or to exploit algal/bacterial species would be promoted, as it has been shown for estuaries (Haynes et al. 2007).

The study of marine biofilms raises a growing interest, especially for human activities, and marine diatoms are considered as attractive sources of new active compounds for biotechnological applications (Fu et al. 2015). Flavobacterium species are important pathogens in aquaculture setting (Duchaud et al. 2007) and have been detected in industrial, domestic, and medical environment biofilms (Basson et al. 2008). In that framework, it is of particular interest to identify a diatom secretome that strongly inhibits the biofilm formation by a Flavobacterium strain. On the contrary, Shewanella sp. IV3014 and Roseobacter sp. IV3009, whose biofilm formation is positively impacted by $N$. phyllepta secretome, belong to genera known to be dominant among the pioneers in marine environments (Salta et al. 2013). It is crucial to understand the first steps of marine biofilm formation in order to efficiently prevent biofouling or conversely to stimulate biofilm formation, which improves for instance larval settlement and metamorphosis of farmed oysters (Yu et al. 2010). Therefore, the molecules of the N. phyllepta EPS bound fraction responsible for Shewanella sp. IV3014 or Roseobacter sp. IV3009 and Flavobacterium sp. II2003 biofilm stimulation and inhibition, respectively, need to be identified.

\section{Acknowledgments}

The authors thank the Conseil Général de la Charente Maritime (France) for the Ph.D. grant of Ibtissem Doghri, the CPER littoral 2007-14 (France), the CNRS EC2CO program MicroBiEn 2013-14 (France), the Région Poitou- 
Charente (France) and the Région Bretagne (France), and the European FEDER funds, for their financial support.

\section{References}

Admiraal W, Peletier H, Brouwer T (1984) The seasonal succession patterns of diatom species on an intertidal mudflat - an experimental analysis. Oikos 42:30-40

Amin SA, Parker M, Armbrust EV (2012) Interactions between diatoms and bacteria. Microbiol Mol Biol Rev 76:667-684

Babor K, Kaláč V, Tihlárik K (1973) Periodate oxidation of saccharides. III. Comparison of the methods for determining the consumption of sodium periodate and the amount of formic acid formed. Chem Zvesti 27:676-680

Basson A, Flemming LA, Chenia HY (2008) Evaluation of adherence, hydrophobicity, aggregation, and biofilm development of Flavobacterium johnsoniae-like isolates. Microb Ecol 55:1-14

Beck MW, Heck KL, Able KW, Childers DL, Eggleston DB, Gillanders BM, Halpern B, Hays CG, Hoshino K, Minello TJ, Orth RJ, Sheridan PF, Weinstein MP (2001) The identification, conservation and management of estuarine and marine nurseries for fish and invertebrates. Bioscience 51:633-641

Bell W, Mitchell R (1972) Chemotactic and growth responses of marine bacteria to algal extracellular products. Biol Bull 143:265-277

Bellinger B, Underwood G, Ziegler S, Gretz M (2009) Significance of diatom-derived polymers in carbon flowdynamics within estuarine biofilms determined through isotopic enrichment. Aquat Microb Ecol 55:169-187

Bendaoud M, Vinogradov E, Balashova NV, Kadouri DE, Kachlany SC, Kaplan JB (2011) Broad-spectrum biofilm inhibition by Kingella kingae exopolysaccharide. J Bacteriol 193:3879-3886

Bruckner CG, Kroth PG (2009) Protocols for the removal of bacteria from freshwater benthic diatom cultures. J Phycol 45:981-986 
Bruckner CG, Bahulikar R, Rahalkar M, Schink B, Kroth PG (2008) Bacteria associated with benthic diatoms from Lake Constance: phylogeny and influences on diatom growth and secretion of extracellular polymeric substances. Appl Environ Microbiol 74:7740-7749

Bruckner CG, Rehm C, Grossart HP, Kroth PG (2011) Growth and release of extracellular organic compounds by benthic diatoms depend on interactions with bacteria. Environ Microbiol 13:1052-1063

Cammen L (1991) Annual bacterial production in relation to benthic microalgal production and sediment oxygen uptake in an intertidal sandflat and an intertidal mudflat. Mar Ecol Prog Ser 71:13-25

Colijn F (1982) Light absorption in the waters of the ems-Dollard estuary and its consequences for the growth of phytoplankton and microphytobenthos. Neth J Sea Res 15:196-216

Consalvey M, Paterson DM, Underwood GJC (2004) The ups and downs of life in a benthic biofilm: migration of benthic diatoms. Diatom Res 19:181-202

Cook PLM, Veuger B, Böer S, Middelburg JJ (2007) Effect of nutrient availability on carbon and nitrogen incorporation and flows through benthic algae and bacteria in near-shore sandy sediment. Aquat Microb Ecol 49:165-180

da Silva ML, de Oliveira da Rocha FA, Odebrecht C, Giroldo D, Abreu PC (2016) Carbohydrates produced in batch cultures of the surf zone diatom Asterionellopsis glacialis Sensu Lato: influence in vertical migration of the microalga and in bacterial abundance. J Exp Mar Biol Ecol 474:126-132

Dang H, Lovell CR (2000) Bacterial primary colonization and early succession on surfaces in marine waters as determined by amplified rRNA gene restriction analysis and sequence analysis of 16S rRNA genes. Appl Environ Microbiol 66:467-475

de Jonge VN, Colijn F (1994) Dynamics of microphytobenthos biomass in the ems estuary. Mar Ecol Prog Ser 104:185-196 
Decho AW (2000) Microbial biofilms in intertidal systems: an overview. Continental Shelf Res 20:1257-1273

Doghri I, Rodrigues S, Bazire A, Dufour A, Akbar D, Sopena V, Sablé S, Lanneluc I (2015) Marine bacteria from the French Atlantic coast displaying high forming-biofilm abilities and different biofilm 3D architectures. BMC Microbiol 15:231

Dubois M, Gilles KA, Hamilton JK, Rebers PA, Smith F (1956)

Colorimetric method for determination of sugars and related substances. Anal Chem 28:350-356

Duchaud E, Boussaha M, Loux V, Bernardet JF, Michel C, Kerouault B, Mondot S, Nicolas P, Bossy R, Caron C, Bessières P, Gibrat JF, Claverol S, Dumetz F, Le Hénaff M, Benmansour A (2007) Complete genome sequence of the fish pathogen Flavobacterium psychrophilum. Nat Biotech 25:763-769

Flemming HC, Wingender J (2010) The biofilm matrix. Nat Rev Microbiol $8: 623-633$

Fu W, Wichuk K, Brynjólfsson S (2015) Developing diatoms for value-added products: challenges and opportunities. Nat Biotech $32: 547-551$

Gärdes A, Iversen MH, Grossart H-P, Passow U, Ullrich MS (2011) Diatom-associated bacteria are required for aggregation of Thalassiosira weissflogii. ISME J 5:436-445

Gontang EA, Fenical W, Jensen PR (2007) Phylogenetic diversity of gram-positive bacteria cultured from marine sediments. Appl Environ Microbiol 73:3272-3282

Goto N, Mitamura O, Terai H (2001) Biodegradation of photosynthetically produced extracellular organic carbon from intertidal benthic algae. J Exp Mar Biol Ecol 257:73-86

Grossart HP, Czub G, Simon M (2006) Algae-bacteria interactions and their effects on aggregation and organic matterflux in the sea. Environ Microbiol 8:1074-1084 
Guillard RRL, Ryther JH (1962) Studies of marine planktonic diatoms. I. Cyclotella nana Hustedt, and Detonula confervaceae (Cleve) gran. Can J Microbiol 8:229-239

Hamels I, Muylaert K, Casteleyn G, Vyverman W (2001) Uncoupling of bacterial production and flagellate grazing in aquatic sediments: a case study from an intertidal flat. Aquat Microb Ecol 25:31-42

Haubois AG, Sylvestre F, Guarini JM, Richard P, Blanchard GF (2005) Spatio-temporal structure of the epipelic diatom assemblage from an intertidal mudflat in Marennes-Oléron Bay, France. Estuar Coast Shelf S $64: 385-394$

Haynes K, Hofmann TA, Smith CJ, Ball AS, Underwood GJC, Osborn AM (2007) Diatom-derived carbohydrates as factors affecting bacterial community composition in estuarine sediments. Appl Environ Microbiol 73:6112-6124

Heydorn A, Nielsen AT, Hentzer M, Sternberg C, Givskov M, Ersbøll BK, Molin S (2000) Quantification of biofilm structures by the novel computer program COMSTAT. Microbiology 146:2395-2407

Jeffrey SW, Humphrey GR (1975) New spectrophotometric equations for determining chlorophylls $a, b, c_{1}$ and $c_{2}$ in higher plants, algae and natural phytoplankton. Biochem Physiol Pflanz 167:191-194

Jiang P, Li J, Han F, Duan G, Lu X, Gu Y, Yu W (2011) Antibiofilm activity of an exopolysaccharide from marine bacterium Vibrio sp. QY101. PLoS One 6:e18514

Jones PR, Cottrell M, Kirchman DL, Dexter SC (2006) Bacterial community structure of biofilms on artificial surfaces in an estuary. Microb Ecol 53:153-162

Khandeparker L, DeCosta PM, Anil AC, Sawant SS (2014) Interactions of bacteria with diatoms: influence on natural marine biofilms. Mar Ecol $35: 233-248$

Kim Y, Oh S, Kim SH (2009) Released exopolysaccharide (r-EPS) produced from probiotic bacteria reduce biofilm formation of 
enterohemorrhagic Escherichia coli O157:H7. Biochem Biophys Res Commun 379:324-329

Lavergne C, Beaugeard L, Dupuy C, Courties C, Agogué H (2014) An efficient and rapid method for the enumeration of heterotrophic prokaryotes in coastal sediments by flow cytometry. J Microbiol Meth 105:31-38

Lebeau TL, Robert JMR (2003) Diatom cultivation and biotechnologically relevant products. II. Current and putative products. Appl Microbiol Biotechnol 60:624-632

Lee JB, Hayashi K, Hirata M, Kuroda E, Suzuki E, Kubo Y, Hayashi T (2006) Antiviral sulfated polysaccharide from Navicula directa, a diatom collected from deep-sea water in Toyama Bay. Biol Pharm Bull 29:2135-2139

Lee JW, Nam JH, Kim YH, Lee KH, Lee DH (2008) Bacterial communities in the initial stage of marine biofilm formation on artificial surfaces. $\mathrm{J}$ Microbiol 46:174-182

Loke MF, Lui SY, Ng BL, Gong M, Ho B (2007) Antiadhesive property of microalgal polysaccharide extract on the binding of Helicobacter pylori to gastric mucin. FEMS Immunol Med Microbiol 50:231-238

Lubarsky HV, Hubas C, Chocholek M, Larson F, Manz W, Paterson DM, Gerbersdorf SU (2010) The stabilisation potential of individual and mixed assemblages of natural bacteria and microalgae. PLoS One 5:e13794

Mack D, Fischer W, Krokotsch A, Leopold K, Hartmann R, Egge H, Laufs $\mathrm{R}$ (1996) The intercellular adhesin involved in biofilm accumulation of Staphylococcus epidermidis is a linear beta-1,6-linked glucosaminoglycan: purification and structural analysis. J Bacteriol 178:175-183

Méléder V, Barillé L, Rincé Y, Morançais M, Rosa P, Gaudin P (2005) Spatio-temporal changes in microphytobenthos structure analysed by pigment composition in a macrotidal flat (Bourgneuf Bay, France). Mar Ecol Prog Ser 297:83-99

Middelburg JJ, Barranguet C, Boschker HTS, Herman PMJ, Moens T, Heip 
CHR (2000) The fate of intertidal microphytobenthos carbon: an in situ ${ }^{13}$ C-labeling study. Limnol Oceanogr 45:1224-1234

O'Toole G, Kaplan HB, Kolter R (2000) Biofilm formation as microbial development. Annu Rev Microbiol 54:49-79

Orvain F, De Crignis M, Guizien K, Lefebvre S, Mallet C, Takahashi E, Dupuy C (2014) Tidal and seasonal effects on the short-term temporal patterns of bacteria, microphytobenthos and exopolymers in natural intertidal biofilms (Brouage, France). J Sea Res 92:6-18

Pamp SJ, Sternberg C, Tolker-Nielsen T (2009) Insight into the microbial multicellular lifestyle via flow-cell technology and confocal microscopy. Cytometry A 75:90-103

Pascal PY, Dupuy C, Richard P, Mallet C, Châtelet EAD, Niquil N (2009) Seasonal variation in consumption of benthic bacteria bymeio- and macrofauna in an intertidal mudflat. Limnol Oceanogr 54:1048-1059

Pierre G, Graber M, Rafiliposon B, Dupuy C, Orvain F, Crignis M, Maugard T (2012) Biochemical composition and changes of extracellular polysaccharides (ECPS) produced during microphytobenthic biofilm development (Marennes-Oléron, France). Microb Ecol 63:157-169

Pitts B, Hamiltonb MA, Zelverc N, Stewart SS (2003) A microtiter-plate screening method for biofilm disinfection and removal. J Microbiol Meth $54: 269-276$

Qin Z, Yang L, Qu D, Molin S, Tolker-Nielsen T (2009) Pseudomonas aeruginosa extracellular products inhibit staphylococcal growth, and disrupt established biofilms produced by Staphylococcus epidermidis. Microbiology 155:2148-2156

Rendueles O, Travier L, Latour-Lambert P, Fontaine T, Magnus J, Denamur E, Ghigo JM (2011) Screening of Escherichia coli species biodiversity reveals new biofilm-associated anti-adhesion polysaccharides. mBio 2(3):e00043-11

Rendueles O, Kaplan JB, Ghigo JM (2013) Antibiofilm polysaccharides. Environ Microbiol 15:334-346 
Ribalet F, Intertaglia L, Lebaron P, Casotti R (2008) Differential effect of three polyunsaturated aldehydes on marine bacterial isolates. Aquat Toxicol 86:249-255

Sablé S, Pons AM, Gendron-Gaillard S, Cottenceau G (2000) Antibacterial activity evaluation of microcin J25 against diarrheagenic Escherichia coli. Appl Environ Microbiol 66:4595-4597

Salta M, Wharton JA, Blache Y, Stokes KR, Briand JF (2013) Marine biofilms on artificial surfaces: structure and dynamics. Environ Microbiol 15:2879-2893

Sayem SA, Manzo E, Ciavatta L, Tramice A, Cordone A, Zanfardino A, De Felice M, Varcamonti M (2011) Antibiofilm activity of an exopolysaccharide from a sponge-associated strain of Bacillus licheniformis. Microb Cell Factories 10:74

Schäfer H, Abbas B, Witte H, Muyzer G (2002) Genetic diversity of "satellite" bacteria present in cultures of marine diatoms. FEMS Microbiol Ecol 42:25-35

Scholz B (2014) Effects of varying pH on the growth and physiology of five marine microphytobenthic diatoms isolated from the Solthörn tidal flat (southern North Sea, Germany). Phycologia 53:252-264

Serôdio J, da Silva JM, Catarino F (1997) Nondestructive tracing of migratory rhythms of intertidal benthic microalgae using in vivo chlorophyll $a$ fluorescence. J Phycol 33:542-553

Shishlyannikov SM, Zakharova YR, Volokitina NA, Mikhailov IS, Petrova DP, Likhoshway YV (2011) A procedure for establishing an axenic culture of the diatom Synedra acus subsp. radians (Kütz.) Skabibitsch from Lake Baikal. Limnol Oceanogr Methods 9:478-484

Smith DJ, Underwood GJC (2000) The production of extracellular carbohydrates by estuarine benthic diatoms: the effects of growth phase and light and dark treatment. J Phycol 36:321-333

Smith PK, Krohn RI, Hermanson GT, Mallia AK, Gartner FH, Provenzano MD, Fujimoto EK, Goeke NM, Olson BJ, Klenk DC (1985) Measurement 
of protein using bicinchoninic acid. Anal Biochem 150:76-85

Staats N, de Winder B, Stal LJ, Mur LR (1999) Isolation and characterization of extracellular polysaccharides from the epipelic diatoms Cylindrotheca closterium and Navicula salinarum. Eur J Phycol 34:161-169

Takahashi E, Ledauphin J, Goux D, Orvain F (2009) Optimising extraction of extracellular polymeric substances (EPS) from benthic diatoms: comparison of the efficiency of six EPS extraction methods. Mar Freshwat Res 60:1201-1210

Underwood G, Kronkamp R (1999) Primary production by phytoplankton and microphytobenthos in estuaries. Adv Ecol Res 29:93-153

Underwood G, Paterson D (2003) The importance of extracellular carbohydrate production by marine epipelic diatoms. Adv Bot Res 40:183-240

Underwood GJC, Paterson DM, Parkes RJ (1995) The measurement of microbial carbohydrate exopolymers from intertidal sediments. Limnol Oceanogr 40:1243-1253

Underwood GJC, Boulcott M, Raines CA (2004) Environmental effects on exopolymer production by marine benthic diatoms: dynamic, changes in composition, and pathways of production. J Phycol 40:293-301

Urakawa H, Yoshida T, Nishimura M, Ohwada K (2000) Characterization of depth-related population variation in microbial communities of a coastal marine sediment using 16S rDNA-based approaches and quinone profiling. Environ Microbiol 2:542-554

Valle J, Da Re S, Henry N, Fontaine T, Balestrino D, Latour-Lambert P, Ghigo JM (2006) Broad spectrum biofilm inhibition by a secreted bacterial polysaccharide. Proc Natl Acad Sci U S A 103:12558-12563

van Duyl FC, de Winder B, Kop AJ, Wollenzien U (1999) Tidal coupling between carbohydrate concentrations and bacterial activities in diatominhabited intertidal mudflats. Mar Ecol Prog Ser 191:19-32 
van Duyl FC, Winder BD, Kop AJ, Wollenzien U (2000) Consequences of diatom mat erosion for carbohydrate concentrations and heterotrophic bacterial activities in intertidal sediments of the ems-Dollard estuary. Cont Shelf Res 20:1335-1349

Windler M, Gruber A, Kroth PG (2012) Technical note: purification of benthic diatoms from associated bacteria using the antibiotic imipenem. $J$ Endocytobiosis Cell Res 62-65

Windler M, Leinweber K, Bartulos CR (2015) Biofilm and capsule formation of the diatom Achnanthidium minutissimum are affected by a bacterium. J Phycol 51:343-355

Yu X, He W, Li H, Yan Y, Lin C (2010) Larval settlement and metamorphosis of the pearl oyster Pinctada fucata in response to biofilms. Aquaculture 306:334-337 